$$
\begin{aligned}
& \left.a_{1}=<d_{1}^{*}\right\rangle=(10,3 \pm 0,1) \mathrm{MKM} ; \\
& a_{2}=\frac{2}{\sqrt{3}}<d_{2}^{*}>=(10,2 \pm 0,2) \mathrm{MKM} .
\end{aligned}
$$

Средний период решетки ФК определяется по формуле

$$
<a>=\frac{a_{1}+a_{2}}{2}=(10,2 \pm 0,2) \mathrm{MKM} .
$$

Видим, что в пределах погрешности измерений среднее значение периода решетки $\Phi К<a>$ совпадает, как и следовало ожидать, с расстоянием между оптоволоконными нитями (10 мкм), из которых изготовлен данный ФК.

\section{Заключение}

Разработана экспериментальная установка для получения брэгговской дифракции света на $2 \mathrm{D}$-фотонной структуре и предложена методика расчета периода решетки двухмерного ФК по его оптической лауэграмме, с помощью которых можно определить структурные параметры ФК. Результаты работы могут быть использованы в учебном процессе для демонстрации основных свойств $Ф К$ и их применения в различных областях науки и техники.

Библиографический список

1. Inoue, K. Photonic crystals: physics, fabrication and applications / K. Inoue, K. Ohtaka - Berlin: Springer, 2004.

2. Yablonovitch, E. Photonic band dtructure / E. Yablonovitch // In: Photonic band gaps and localization - N.-Y.: Plenum Press; 1993. - P. 207-234.

3. Наими, Е. К. Фотонные кристаллы с показателем преломления, модулируемым ультразвуком / Е. К. Наими, Ю. Х. Векилов // Изв. вузов. Материалы электрон. техники. - 2011. - № 1. - C. $21-24$.

4. Сивухин, Д. В. Общий курс физики. Оптика / Д. В. Сивухин - М. : Наука, 1980. - С. 384-393.

Работа въполнена при ббинансовой поддержке программы "Развитие научного потеницала высшей школъ» Министерства образования и науки РФ (грант РПН.2.1./1552).

УДК 621.315 .592

\title{
СРАВНИТЕЛЬНЫЕ ХАРАКТЕРИСТИКИ ОДНОСЛОЙНЫХ И ДВУХСЛОЙНЫХ ТЕНЗОПРЕОБРАЗОВАТЕЛЕЙ ДАВЛЕНИЯ НА ОСНОВЕ СТРУКТУР КРЕМНИЙ-НА-САПФИРЕ
}

Рассмотрены сравнительные характеристики полупроводниковых тензорезисторных преобразователей давления на основе структур кремний-насапфире. Исследованы два вида конструкции тензорезисторных преобразователей: с однослойным упругим элементом на керамическом основании и с двухслойным упругим элементом из сапфира и металла. Показано, что однослойные тензорезисторные преобразователи обладают лучшими характеристиками, чем двухслойные, но они имеют ограниченное применение по диапазонам измеряемого давления.

Ключевые слова: датчик давления, тензопреобразователь давления, структура кремнийна-сапфире.

\section{() 2011 г. А. А. Устинов, Ю. С. Нагорнов* , А. И. Козлов ЗАО МИДАУС, *ГОУ ВПО “Ульяновский государственный университет”}

Полупроводниковые тензорезисторные преобразователи (ТП) давления широко используют в измерительных системах. При этом с каждым годом к метрологическим характеристикам датчиков предъявляют все более жесткие требования, в том числе к точности и температурной погрешности. Наряду с характеристиками, которые определяют точность ТП, существуют характеристики качества. В их число входят следующие:

- температурный дрейф (ТД) выходного сигнала;

- гистерезис первого нагружения (ГПН), т. е. изменение начального выходного сигнала после первого обдавливания номинальным давлением;
- температурный невозврат начального выходного сигнала - изменение выходного сигнала после воздействия температуры и временная стабильность выходного сигнала в диапазоне рабочих температур.

В России получили широкое распространение (разработка и производство) интегральные ТП с полупроводниковыми чувствительными элементами (ПЧЭ) на основе структур кремний-на-сапфире (КНС). В ТП давления используют мостовую схему из кремниевых тензорезисторов (TP). За счет соответствующего расположения на мембране радиальные ТР обладают одним знаком тензочувствительности, а тангенциальные ТP - противоположным. Существуют два основных 
Характеристики однослойных и двухслойных тензорезисторных преобразователей

\begin{tabular}{|l|c|c|c|c|}
\hline \multicolumn{1}{|c|}{ Вид Тп } & Тд, $\frac{\%}{10^{\circ} \mathrm{C}}$ & ГПН, \% & $\begin{array}{c}\text { Температурный } \\
\text { невозврат, \% }\end{array}$ & Стабильность, \% \\
\hline $\begin{array}{l}\text { С однослойным упругим элементом } \\
\text { из саприра }\end{array}$ & $0,02-0,06$ & $0,002-0,003$ & $0,011-0,012$ & $0,01-0,03$ \\
\hline $\begin{array}{l}\text { С двухслойным упругим элементом } \\
\text { из саприра и металла }\end{array}$ & $0,11-0,14$ & $0,08-0,25$ & $0,03-0,17$ & $0,02-0,05$ \\
\hline
\end{tabular}

Обозначения: ТП — тензорезисторный преобразователь; Тд — температурный дрейфр; ГПН — гистерезис первого нагружения.
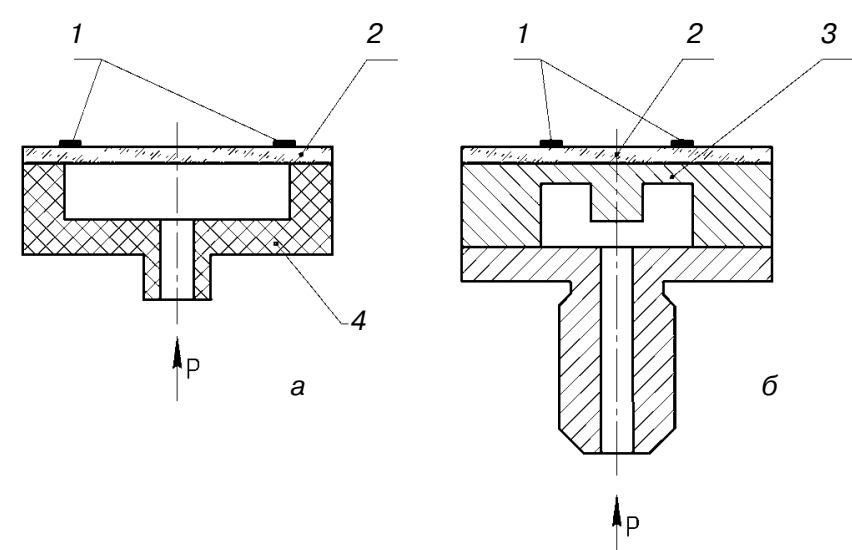

Рис. 1. Схематическое изображение конструкций ТП давления с однослойным упругим элементом из сапфира (а) и двухслойным упругим элементом из сапфира и металла (б): 1 - ТР; 2 - ПЧЭ; 3 - металлическая упругая мембрана; 4 - керамическое основание

вида конструкции ТП, использующих ПЧЭ на основе структуры $\mathrm{KHC}^{1}$ :

- с однослойным упругим элементом из сапоира (рис. 1, a);

- с двухслойным упругим элементом из сапфира и металла (рис. 1, б).

Наиболее широко применяют двухслойные ТП. Из-за существенного различия коэфорициентов температурного расширения (KTP) сапфира и титана такие ТП имеют сильную температурную зависимость выходного сигнала. В характеристики двухслойных ТП значительный вклад дают свойства металла и соединительного слоя. ТП с однослойным упругим элементом представляет собой ПЧЭ, напаянный на керамическое основание. В качестве припоя исполь- зуют стеклопорошок. Точностные параметры такого ТП сравнимы с серийно выпускаемыми двухслойными ТП. Из-за лучшего согласования КТР мембраны (саприр) и основания (керамика) однослойные ТП обладают меньшими температурными погрешностями ${ }^{2}$; недостатком таких ТП являются ограничения по диапазонам измеряемого давления.

Ниже приведены результаты измерения перечисленных выше характеристик однослойных и двухслойных ТП:

- ТД начального выходного сигнала в диапазоне температур $-40-160{ }^{\circ} \mathrm{C}$;

- ГПН при температурах $-40,30$ и $80^{\circ} \mathrm{C}$;

- температурный невозврат начального выходного сигнала на $-40{ }^{\circ} \mathrm{C}$ после воздействия $80{ }^{\circ} \mathrm{C}$ для однослойных ТП и на $30{ }^{\circ} \mathrm{C}$ после воздействия $150{ }^{\circ} \mathrm{C}$ для двухслойных ТП;

- стабильность выходного сигнала при выдержке на температуре $160{ }^{\circ} \mathrm{C}$ в течение 10 сут. Измеренные данные в процентах от диапазона изменения выходного сигнала представлены в таблице.

Как видно из таблицы, однослойные ТП обладают лучшими характеристиками, чем двухслойные. Этого можно было ожидать, учитывая монокристаллическую структуру сапфировой мембраны. Керамические ТП более стабильны. Это, по-видимому, связано с тем, что в их конструкции нет металла, в котором присутствует пластическая деформация. Используемое в качестве припоя стекло ограничивает рабочий диапазон температур однослойных ТП. Такие ТП можно рекомендовать для создания высокоточных и сравнительно недорогих барометров с электрическим выходом.

\footnotetext{
${ }^{1}$ Стучебников, В. М. Структуры КНС как материал для тензопреобразователей механических величин / В. М. Стучебников // Радиотехника и электроника. - 2005. - Т. 50, № 6. - С. 678-696.

2 Стучебников, В. М. Исследование температурного дрейфа и нелинейностей тензопреобразователей давления на основе керамики / В. М. Стучебников, А. А. Устинов, Ю. С. Нагорнов // Изв. вузов. Поволжский регион. Техн. науки. 2010. - № 2 (14). - C. $62-69$.
} 